
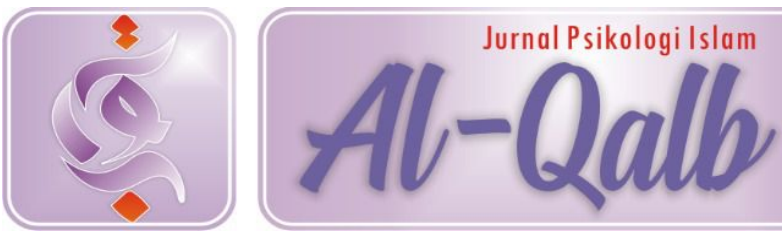

EISSN : 2686-326X

ISSN : 2085-8647

https://ejournal.uinib.ac.id/jurnal/index.php/alqalb/index

\title{
SUBJECTIVE WELL BEING MAHASISWI SAAT MENGALAMI GANGGUAN MENSTRUASI
}

Received: $22^{\text {th }}$ September 2018; Revised: $08^{\text {th }}$ October 2018; Accepted: $23^{\text {th }}$ November 2018

\section{Hasnawati}

UIN Imam Bonjol Padang

Email: hasnawati@uinib.ac.id

Elyusra Ulfah

UIN Imam Bonjol Padang

Email: elyusraulfah@uinib.ac.id

Putri Dewi Anggraini

UIN Imam Bonjol Padang

Email: putridewianggraini06@yahoo.com

\begin{abstract}
ABSTRAK. Penelitian ini dilatarbelakangi dengan adanya mahasiswi yang mengalami gangguan menstruasi. Mahasiswi mengalami gangguan menstruasi seperti merasakan sakit dan nyeri yang berlebihan, merasakan takut dan cemas saat menstruasi. Penelitian ini bertujuan untuk mengetahui subjective well being pada mahasiswi saat mengalami menstruasi ditinjau dari komponen kepuasan hidup secara keseluruhan, komponen afek positif dan komponen afek negatif.

Penelitian ini menggunakan metode penelitian kualitatif dengan model penelitian fenomenologi. Subjek penelitian ditentukan dengan menggunakan teknik purposive sampling (sesuai tujuan penelitian) yaitu dua orang mahasiswi yang mengalami gangguan menstruasi. Pengumpulan data penelitian dilakukan melalui wawancara. Analisis data dalam penelitian ini mengacu kepada analisis model interaktif menurut Miles \& Huberman.

Hasil penelitian menunjukkan bahwa dilihat dari komponen kepuasan hidup secara keseluruhan, subjek yang mengalami gangguan menstruasi dapat menerima kondisi yang dirasakannya dan berpikir positif terhadap diri, serta memiliki harapan yang tinggi untuk menghilangkan rasa sakit saat mengalami gangguan menstruasi. Dilihat dari komponen afek positif, subjek berusaha untuk berpikir positif dan mendapat dukungan serta arahan dari orangtua saat mengalami gangguan menstruasi seperti dengan meminum obat herbal saat mengalami gangguan menstruasi. Dilihat dari komponen afek negatif, subjek merasakan takut can cemas saat mengalami gangguan menstruasi dan khawatir memeriksakan kondisinya ke dokter.
\end{abstract}

Kata kunci: Subjective well being, mahasiswi, gangguan menstruasi

\section{A. PENDAHULUAN}

Menstruasi adalah proses peluruhan lapisan dalam atau endometrium yang banyak mengandung pembuluh darah dari uterus melalui vagina (Kumalasari, 2013). Menstruasi selalu dialami oleh wanita normal disetiap bulannya. Pada saat wanita mengalami menstruasi, perilaku dan emosi wanita tersebut sering mengalami perubahan yang drastis dan terkadang emosinya juga sering tidak stabil. Perubahan yang dialami wanita ketika menstruasi seperti mudah marah, pingsan tiba-tiba. Menstruasi merupakan proses biologis yang terkait 
dengan pencapaian kematangan seks, kesuburan, ketidakhamilan, normalitas, kesehatan tubuh, dan bahkan pembaharuan tubuh itu sendiri. Secara Kematangan seksual (menstruasi, kematangan fisik) ini disebabkan antara lain oleh konstitusi fisik individual, ras, suku bangsa, iklim, cara hidup, dan lingkungan. Menstruasi sebagai salah satu ciri khas dari kedewasaan wanita. Menstruasi pada wanita adalah suatu pendarahan rahim yang sifatnya fisiologik (normal) yang datangnya teratur setiap bulan (siklus haid). Timbulnya perdarahan tersebut sebagai akibat perubahan hormonal yaitu estrogen dan progesteron (Hawari, 1997).

Menurut Hanafiah, panjang siklus haid ialah jarak antara tanggal mulainya haid yang lalu dan mulainya haid berikutnya. Hari mulainya perdarahan dinamakan hari pertama siklus, karena jam mulainya haid tidak diperhitungkan dan tepatnya waktu keluar haid dari ostium uteri eksternum tidak dapat diketahui, maka panjang siklus mengandung kesalahan kurang dari 1 hari. Panjang siklus haid yang normal atau dianggap sebagai siklus haid yang klasik ialah 28 hari, terapi variasinya cukup luas, bukan saja antara beberapa wanita tetapi juga pada wanita yang sama. Juga pada kakak beradik bahkan saudara kembar, siklusnya tidak terlalu lama.

Panjang siklus haid dipengaruhi oleh usia seseorang. Rata-rata panjang siklus haid pada gadis usia 12 tahun ialah 25,1 hari, pada wanita usia 43 tahun 27,1 hari dan pada wanita usia 55 tahun 51,9 hari. Jadi sebenarnya panjang siklus haid 28 hari itu tidak sering dijumpai. Dari pengamatan Hartman pada kera ternyata bahwa hanya $20 \%$ saja panjang siklus haid 28 hari. Panjang siklus yang biasa pada manusia ialah 25-32 hari dan kira-kira 97\% wanita yang berovulasi siklus haidnya berkisar antara 18-42 hari. Jika siklusnya kurang dari 18 hari atau lebih dari 42 hari dan tidak teratur, biasanya siklusnya tidak berovulasi (anovulatoar). Lama haid biasanya antara 3-
5 hari, ada yang 1-2 hari diikuti darah sedikit-dikitnya kemudian dan ada yang sampai 7-8 hari. Pada setiap wanita biasanya lama haid itu tetap. Jumlah darah yang keluar rata-rata 33,2 lebih kurang $16 \mathrm{cc}$. Pada wanita yang lebih tua biasanya darah yang keluar lebih banyak. Pada wanita dengan anemi defisiensi besi jumlah darah haidnya juga lebih banyak. Jumlah darah haid lebih dari 80 cc dianggap patologik. Darah haid tidak membeku ini mungkin disebabkan fibrinolisin (Wiknjosastro, 2009: 103-104).

Bagi kebanyakan wanita, menstruasi bagaikan kejadian yang menyimpan misteri dan berulang-berulang disetiap bulannya. Penelitian Dalton menyatakan bahwa sekitar $70 \%$ wanita mengalami nyeri pada saat menstruasi dalam kehidupan mereka. Kondisi ini memunculkan kesan bahwa nyeri yang menyertai siklus haid adalah suatu keharusan. Jika ada kelompok wanita yang benar-benar abnormal adalah kelompok $30 \%$ yang beruntung tidak pernah menderita nyeri sama sekali (Kingston, 1991). Maksud dari hasil penelitian Dalton, wanita yang mengalami nyeri pada saat menstruasi termasuk pada kategori yang normal, yang mana dijelaskan bahwa sekitar $70 \%$ wanita mengalami nyeri menstruasi dan $30 \%$ tidak mengalami nyeri menstruasi, Jadi wanita yang dianggap normal ketika mengalami nyeri saat menstruasi dianggap suatu keharusan.

Pembahasan tentang menstruasi tidak terlepas dari pandangan Islam. Menurut Dahri, dalam Islam menstruasi disebut dengan haid. Dalam pandangan Islam tentang haid sebagaimana dinyatakan oleh al-Qur'ân, mengandung sebuah pemikiran baru yang berbeda dengan tradisi Yahudi sebelumnya. Dalam tradisi Yahudi, perempuan yang sedang haid dianggap sebagai perempuan kotor yang bisa mendatangkan bencana sehingga harus diasingkan dari masyarakat (Umar, 1998: 121). 
Hal ini dijelaskan dalam firman Allah SWT dalam surat Al-Baqarah ayat 222 yang artinya:

"Mereka bertanya kepadamu tantang haidh. Katakanlah: Haidh itu adalah suatu kotoran. Oleh sebab itu hendaklah kamu menjauhkan diri dari wanita diwaktu haidh dan janganlah kamu mendekati mereka, sebelum mereka suci. Apabila mereka telah suci, maka campurilah mereka itu ditempat yang diperintahkan Allah kepadamu. Sesungguhnya Allah menyukai orang-orang yang taubat dan menyukai orang-orang yang mensucikan diri (QS. Al-Baqarah: 222)".

Ayat di atas menjelaskan bahwa menstruasi ini merupakan darah kotor, yang mana dalam segi agama wanita yang sedang mengalami menstruasi tidak boleh melakukan sesuatu seperti sholat, karena ketika wanita sedang menstruasi, berarti wanita tersebut dalam keadaan tidak suci.

Dalam Islam, perempuan berumur 9 tahun yang mengeluarkan darah haid menandakan perempuan tersebut telah baligh. Perempuan yang baligh kemudian disebut mukallaf (orang yang dibebani). Artinya, perempuan tersebut telah memiliki kewajiban untuk melaksanakan sholat, puasa, zakat, dan Haji jika mampu. Ketika masa haid, perempuan muslim tidak diperbolehkan (haram) melakukan hal-hal berikut yaitu sholat, puasa, haji, memegang Al-quran, bersetubuh, dan berdiam diri di Masjid jika khawatir tembus (jika tidak,maka diperbolehkan).

Gangguan menstruasi merupakan masalah yang sering terjadi pada wanita. Gangguan ini sering merupakan sumber kecemasan bagi wanita. Gangguan menstruasi yang umum terjadi adalah amenorea, pendarahan uterus abnormal atau berlebihan, dysmenorea dan sindrom premenstruasi (Owen 2005). Menstruasi yang tidak teratur dapat disebabkan karena adanya gangguan hormon maupun faktor psikis seperti, stres, depresi dan lain-lain yang dapat memegaruhi kerja hormon.

Wanita yang mengalami menstruasi bisa mengarah pada dampak positif dan dampak negatif serta kondisi emosional dan well-being dalam dirinya. Saat wanita tidak dapat mengatasi masalah yang sedang dihadapinya maka akan timbul emosi yang tidak menyenangkan dalam dirinya. Keadaan ini dapat menyebabkan individu yang bersangkutan merasa tidak puas dan tidak bahagia didalam kehidupanya. Menurut Diener, Suh Oishi, 1997 (dalam Nisfiannor, 2004) pengalaman internal yang dialami oleh individu tersebut dapat digambarkan melalui istilah subjective well being (SWB). Ketidakstabilan emosi ini dapat memengaruhi subjective well being atau kesejahteraan subjektif yang dimiliki seseorang. Subjective Well-Being atau kesejahteraan subyektif didefenisikan sebagai suatu fenomena yang meliputi evaluasi kognitif dan emosional individu terhadap kehidupan mereka, seperti apa yang disebut orang awam sebagai kebahagiaan, ketenteraman, berfungsi penuh dan kepuasan hidup (Dieners, Oishi dan Lucas, 2003: 404). Kesejahteraan subjektif (SWB) juga didefinisikan sebagai evaluasi kognitif dan afektif seseorang dari hidupnya (Diener, Oishi dan Lucas, 2002:63).

Subjective well being (kesejahteraan subjektif) adalah persepsi seseorang terhadap pengalaman hidupnya yang terdiri dari evaluasi kognitif dan afektif terhadap hidup dan merepresentasikan dalam kesejahteraan psikologis. Kesejah-teraan subjektif merupakan salah satu kajian dalam psikologi positif, didefinisikan sebagai suatu fenomena yang meliputi evaluasi kognitif dan emosional individu terhadap kehidupan mereka, seperti apa yang disebut orang awam sebagai kebahagiaan, ketenteraman, berfungsi penuh, dan kepuasan hidup (Diener, Oishi, \& Lucas, 2003). Menurut Diener 1984 (dalam Larsen, 2008) bahwa kesejahteraan subjectif memiliki tiga 
komponen, yaitu: kepuasan hidup secara keseluruhan, afek positif dan afek negatif.

Pada saat wanita mengalami menstruasi, perilaku dan emosi wanita tersebut sering mengalami perubahan yang drastis dan terkadang emosinya juga sering tidak stabil. Wanita yang mengalami dampak positif (baik) dalam dirinya terkadang mampu mengontrol emosi dan perilakunya. Tetapi sebaliknya, jika wanita tersebut mengalami dampak negatif (buruk) ketika menstruasi, wanita tersebut akan susah untuk mengontrol emosi dan periakunya. Perilaku merupakan aktivitas yang ada pada individu atau organisme tidak timbul dengan sendirinya, tetapi sebagai akibat dari stimulus yang diterima oleh organisme yang bersangkutan baik stimulus eksternal maupun stimulus internal (Walgito, 2003).

Seperti wawancara awal yang penulis lakukan terhadap NV sebagai berikut:

"Sewaktu menstruasi saya sering sakit perut, rasanya sakiiiit banget. Rasanya itu nggak bisa diceritakan. Kalau lagi haid tu bawaanya marah-marah aja, kayak harimau mau menerkam mangsa. Badan aja rasanya lemah banget kayak nggak ada tulang, trus rasanya pengen males-malesan, males ngapa-ngapain, sampai-sampai makanpun males. Kalau dibawa makan tu rasanya makin sakit ajja. Pokoknya males semuanya. Pengenya cuma tidur aja. Pernah dulu sangkin nggak bisa nahan sakit perut haid sampai pingsan pas kuliah" (Wawancara, 23/05/2015).

Masa

mempengaruhi NV dalam menjalani aktivitasnya. Dampak negatif dan emosi yang tidak stabil yang dimiliki NV ketika sedang mengalami menstruasi. Hal yang sama juga diungkapkan oleh RA seperti yang diungkapkanya: "kalau menstruasi sih dibilang benar-benar sakitnya cuma pas hari pertama sampai hari ketiga ajja, selepas itu udah tidak begitu sakit" (Wawancara, 07/09/2015).
Menurut ungkapan diatas dapat dipahami bahwa RA sering merasakan sakit ketika menstruasi pada saat hari pertama sampai hari ketiga. Hal yang berbeda dialami oleh SC seperti yang diungkapkannya:

"rasa sakit sewaktu haid sangat sering saya rasakan, rasa tidak nyaman, rasa risih. Tapi saya sering berfikir namanya juga perempuan masa haid itu mungkin sudah jadi makanan sekali sebulan. Kadang sewaktu haid tu rasa sakitnya mungkin nggak bisa diungkapkan. Sebagian besar cewek kalau lagi haid tu pengennya malesmalesan, tapi kalau saya pribadi nggak. Walaupun sakit haid aktifitas tetap saya jalankan. Kalau nggak dikerjakan ntar malah numpuk. Pas haid saya masih bisa jaga emosi saya, saya nggak begitu suka marah-marah, marah-marah sih jarang" (Wawancara, 26/09/15).

Dari hasil wawancara, SC tetap menjalani hari-harinya walaupun sedang menstruasi. SC juga tetap mengendalikan perilaku dan emosinya ketika menstruasi dan berusaha untuk tidak malas ketika menstruasi.

Subjective well-being melihat dampak positif dan negatif wanita dalam menghadapi menstruasi. Selain itu, subjective well being juga dapat memengaruhi perilaku wanita dalam menstruasi tersebut. Wanita yang memiliki dampak emosi dan perilaku negatif ketika menstruasi terkadang merasa kalau menstruasi membuat wanita tersebut bersikap malas dan tidak memiliki semangat dalam keseharianya. Sebaliknya, wanita yang memiliki dampak emosi dan perilaku positif ketika menstruasi mampu untuk tetap mengontrol emosi dan perilakunya.

Berdasarkan dari berbagai fenomena dan wawancara di atas maka penulis tertarik untuk mengkaji lebih jauh tentang fenomena ini secara spesifik dengan judul "Subjective Well Being Mahasiswi Saat Mengalami Gangguan Menstruasi”. 


\section{B. METODE}

Penelitian ini menggunakan metode penelitian kualitatif. Model penelitian yang digunakan dalam penelitian ini adalah model fenomenologi (phenomenology). Penelitian fenomenologi berusaha untuk mencari arti secara psikologis dari suatu pengalaman individu terhadap suatu fenomena melalui penelitian yang mendalam dalam konteks kehidupan sehari-hari subjek yang diteliti. Fenomenologi juga berusaha untuk mempelajari dan mengungkap konteksnya yang khas serta persiapan yang matang dan komprehensif untuk mendapatkan kepercayaan penuh dari subjek yang diteliti sehingga keterdekatan dapat diperoleh dan dapat mendukung penelitian (Herdiansyah, 2010: 67).

Subjek dalam penelitian ini adalah mahasiswi yang mengalami gangguan menstruasi. Teknik pengambilan subjek yang digunakan dalam penelitian ini adalah teknik purposive sampling, yaitu subjek yang sengaja dipilih berdasarkan karakteristik yang telah ditentukan dalam penelitian. Adapun karakteristik subjek dalam penelitian ini adalah:

a. Mahasiswi yang masih aktif kuliah di IAIN Imam Bonjol Padang.

b. Mahasiswi yang sedang mengalami gangguan menstruasi, seperti rasa nyeri dan pingsan ketika menstruasi.

c. Mahasiswi yang berumur 20-30 tahun. Alasanya, karena pada usia 20-30 tahun paling sering terjadinya nyeri menstruasi yang disebabkan karena kelainan (Kumalasari, 2013: 70).

Teknik pengumpulan data dalam penelitian ini menggunakan wawancara. Menurut Moleong (2010: 186) wawancara merupakan percakapan dengan maksud tertentu. Percakapan itu dilakukan oleh dua pihak yaitu pewawancara (penulis) mengajukan pertanyaan terhadap terwawancara yang memberikan jawaban atas pertanyaan. Peneliti menggunakan wawancara terhadap beberapa orang mahasiswi yang mengalami gangguan menstruasi untuk mengetahui bagaimana subjective well being dalam dirinya.

Analisis data dalam penelitian ini menggunakan Teknik analisis data model interaktif menurut Miles \& Huberman. Menurut Creswell (dalam Herdiansyah, 2011: 163-179) teknik analisis data yang lebih mudah dipahami dan lebih sesuai dalam penelitian kualitatif adalah teknik analisis data model interaktif menurut Miles \& Huberman. Teknik analisis data model interaktif menurut Miles \& Huberman terdiri atas empat tahapan yang harus dilakukan. Tahapan pertama adalah tahap pengumpulan data, tahapan kedua adalah tahap reduksi data, tahapan ketiga adalah tahap display data, dan tahapan keempat adalah tahap penarikan kesimpulan atau tahap verifikasi.

\section{HASIL DAN PEMBAHASAN}

Berdasarkan hasil wawancara yang peneliti lakukan terhadap subjek AY terdapat jawaban yang bervariasi dan memenuhi pertanyaan-pertanyaan yang peneliti berikan berdasarkan komponen dan indikator yang ada, dimana komponen pertama adalah kepuasan hidup secara keseluruhan dengan indikator sehubungan dengan rasa senang atau tidak senang.

Saat pertama kali menstruasi AY berfikir tentang ketakutan dan kecemasan yang dirasakanya dan pada akhirnya AY dapat menghilangkan rasa takut dan cemas yang dia rasakan. Seperti yang ia ungkapkan bahwa:

"Oo waktu dulu tu yang muncul difikiran saya awalnya dulu ya cemas tadikan takut ada apa ini kenapa oo seperti ini sosoalnya dulu diwaktu SMP itu teman-teman yang seangkatan sudah ada yang duluan menstruasi tapi gak terlalu peka apa itu itu 
yang disama teman-teman oo trus diwaktu datang awal pertama menstruasi itu oo agak ya takut cemas ya tapi diarahan sama orang tua akhirnya fikiran gak terlalu takut atau apalagi gitu (W1/L57-63)".

Saat menstruasi AY selalu merasakan nyeri. Orang tua AY menganggap kalau anaknya sudah besar dan sudah bisa membedakan antara yang baik dan buruk. Ketika menstruasi AY selalu mengalami gangguan, tetapi gangguan yang dialami AY tidak begitu parah dan saat menstruasipun AY selalu tidak kuat ketika menahan sakit dan nyeri yang dirasakannya.

Berikutnya komponen kedua adalah afek positif dengan indikator merasakan emosi yang positif. Dari hasil wawancara diketahui bahwa AY selalu menghitung dalam jangka waktu berapa lama ia mengalami menstruasi. Saat AY sudah mengalami menstruasi, orang tua AY tidak ada memberikan peraturan kepada AY, tapi orang tua AY Cuma memberikan arahan kepada AY dan mengingatkan kalau AY sekarang sudah dewasa dan harus pandai menjaga diri. Reaksi AY ketika orang tuanya memberikan peraturan baru itu AY sangat senang dan malahan AY menganggap kalau orang tuanya memberikan peraturan itu menandakan bahwah orang tuanya sangat menyayanginya.

Selanjutnya komponen ketiga adalah afek negatif dengan indikator merasakan emosi yang negatif. Dari hasil wawancara diketahui bahwa AY tidak menyukai sakit perut ketika menstruasi. Hal itu diungkapkan dari pertanyaan "coba anda ceritakan hal-hal apa saja yang paling tidak anda sukai saat anda mengalami menstruasi. Keluhan yang dirasakan AY saat menstruasi itu Cuma sakit perut berlebihan dan AY tudak bisa menahan sakit perut yang dia rasakan, karena menahan sakit yang dia rasakan sampai-sampai mukanya pucat.

Berdasarkan hasil wawancara yang peneliti lakukan terhadap subjek MR terdapat jawaban yang bervariasi dan memenuhi pertanyaan-pertanyaan yang peneliti berikan berdasarkan komponen dan indikator yang ada, dimana komponen pertama adalah kepuasan hidup secara keseluruhan dengan indikator sehubungan dengan rasa senang atau tidak senang. MR mengalami menstruasi untuk pertama kalinya ketika ia berada di kelas 2 SMP dan MR tidak merasakan apa-apa dan juga tidak merasakan sakit. MR merasa terkejut dan diiringi dengan senang ketika dia mengalami menstruasi untuk pertama kalinya. MR menstruasi pertama kalinya pada usia 15 tahun, dan pada usia itu ia merasa sudah dewasa dan sudah bisa mengerti tentang pertumbuhan dan perkembangan dirinya.

Ketika MR mengalami menstruasi untuk pertama kalinya ia tidak merasakan nyeri. Namun MR sering mengalami keterlambatan ketika menstruasi dan menstruasinya sering datang tidak teratur. Ketika menstruasi MR sering mengalami siklus haid yang tidak normal. Saat MR mengalami siklus haid yang tidak normal ia sangat ingin konsul ke dokter, tetapi langkah pertama yang ia lakukan yaitu membuat obat pahit bersama orang tuanya dan meminum obat pahit tersebut. Menurut MR siklus menstruasi yang tidak normal itu seperti menstruasi yang datang tidak teratur. MR pernah merasakan sakit saat menstruasi sampai rasanya MR hampir mengalami pingsan.

MR pernah mengalami gangguan saat menstruasi, saat hari pertama menstruasi ia merasakan darah haid itu keluarnya sedikit tapi dalam jangka waku sampai 15 hari dan tidak lancar. Saat menstruasi MR sering merasakan ganguan seperti sakit perut yang sangat sakit, kaki keram dan pinggang juga sakit, saat menstruasi MR juga sering marahmarah. Ketika menstruasi, MR hanya bisa menahan sakitnya sampai dia hampir pingsan, tapi jika MR pingsan berarti ia tidak kuat untuk menahan sakit dan nyeri saat menstruasi dan saat nyeri menstruasi 
MR lebih memilih untuk tidur dan tidak pernah kerumah sakit.

Berikutnya komponen kedua adalah afek positif dengan indikator merasakan emosi yang positif. Dari hasil wawancara diketahui bahwa MR merasa sudah remaja saat mengalami menstruasi tersebut dan selalu berpikir positif.

Selanjutnya komponen ketiga adalah afek negatif dengan indikator merasakan emosi yang negatif. Dari hasil wawancara diketahui bahwa MR sering merasa cemas karena haidnya yang datang tidak teratur. MR memikirkan tentang keluhan nyeri yang ia rasakan itu bisa jadi diakibatkan oleh gumpalan darah yang besar yang mana penyebab dari gumpalan darah itu terjadi karena haidnya yang datang dalam sekali 3 bulan atau 5 bulan.

Berdasarkan hasil wawancara pada subjek bahwa AY memiliki subjective well being yang baik dari segi kepuasan hidup secara keseluruhan, afek positif dan afek negatif. Namun AY memiliki lingkungan yang memberi perhatian ditandai dengan memberikan solusi untuk berobat kedokter. Kemudian AY memiliki pribadi yang mudah tersinggung dan sensitive yang tinggi terhadap persoalan dalam lingkungan dan subjek AY juga memiliki harapan yang tinggi untuk menghilangkan rasa sakit yang dia rasakan.

Berdasarkan hasil wawancara pada subjek bahwa MR memiliki subjective well being yang baik dari segi kepuasan hidup secara keseluruhan, afek positif dan afek negatif. Namun MR memiliki lingkungan yang memberi perhatian ditandai dengan memberikan solusi untuk berobat kedokter dan alternatif lain. Kemudian MR memiliki pribadi yang sensitif yang tinggi terhadap persoalan dalam lingkungan dan subjek MR juga memiliki harapan yang tinggi untuk menghilangkan rasa sakit dan dapat kembali merasakan haid yang teratur seperti wanitawanita pada umumnya.

\section{SIMPULAN}

Hasil penelitian menunjukkan bahwa dilihat dari komponen kepuasan hidup secara keseluruhan, subjek yang mengalami gangguan menstruasi dapat menerima kondisi yang dirasakannya dan berpikir positif terhadap diri, serta memiliki harapan yang tinggi untuk menghilangkan rasa sakit saat mengalami gangguan menstruasi.

Dilihat dari komponen afek positif, subjek berusaha untuk berpikir positif dan mendapat dukungan serta arahan dari orangtua saat mengalami gangguan menstruasi seperti dengan meminum obat herbal saat mengalami gangguan menstruasi.

Dilihat dari komponen afek negatif, subjek merasakan takut can cemas saat mengalami gangguan menstruasi dan khawatir memeriksakan kondisinya ke dokter.

\section{DAFTAR KEPUSTAKAAN}

Compton, W.C. (2008). Introduction to Positive Psychology. New York: Thomson Wodsworth.

Diener, E. Oishi, S. \& Lucas, R.E. (2002). Subjective Well Being: The Science of Happiness and Life Satisfaction. In C.R Snyder \& S.J Lopez (Ed). Handbook of Positive Psychology. Oxford and New York: Oxford University Press.

Diener, E. Oishi, S \& Lucas, R.E. (2003). Personality, Culture and Subjective Well Being: Emotional and Cognitive Evaluations of Life. Annual Review of Psychology, 54 (1), 403-425.

Gangguan Menstruasi pada Wanita. http://www.menstruasi.org

Greenspan, S. Francis, B. D. John. (1998). Endroklinology Dasar dan Klinik, edisi IV. Jakarta: EGC. 
Hefferon, K \& Boniwell, I. (2011). Positive Psychology: Theory, Research and Applications. New York.

Herdiansyah, Haris. (2010). Metodologi Penelitian Kualitatif Untuk Ilmu Sosial. Jakarta: Salemba Humanika.

Kingston, B. (1991). Mengatasi Nyeri Haid. Cetakan 3. Jakarta: Arcan.

Kumalasari, I. (2013). Kesehatan Reproduksi. Jakarta: Salemba Medika.

Larsen, R.J \& Michael, Eid. (2008). Ed Diener and The Science Of Subjective Well Being. Dalam Michael, Eid \& Larsen, R.J (Eds). The Science Of Subjective Well Being. New York: The Guilford Press.

Mesarini, B.A. (2013). Stres dan Mekanisme Koping Terhadap Gangguan Siklus Menstruasi pada Remaja Putri. Jurnal STIKES Vol.6 No.1.

Moleong, Lexy J. (2010). Metodologi Penelitian Kualitatif. Bandung. PT Remaja Rosdakarya.

Natasya, D.A. (2013). Subjective Well Being Pada Guru Sekolah Menengah. Calyptra: Jurnal Ilmiah Mahasiswa Universitas Surabaya Vol.2 No.2. http://journal.ubaya.ac.id/index

Owen, Elisabeth. (2005). Panduan Kesehatan bagi Wanita. Jakarta: Prestasi Pustakaraya.
Poerwandari, Kristi. (2005). Pendekatan Kualitatif. Jakarta: LPSP3 UI.

Putri, N.A. (2013). Subjective Well Being Mahasiswa yang Menggunakan Internet Secara Berlebihan. Calyptra: Jurnal Ilmiah Mahasiswa Universitas Surabaya Vo.2 No.1. http://journal.ubaya.ac.id/index

Saifuddin, A.B. (2008). Ilmu Kebidanan. Jakarta: PT. Bina Pustaka Sarwono Prawirohardjo.

Sastrawinata, S. (1983). Obstetri Fisiologi. Bandung: Eleman.

Sulistina, D.R (2009). Hubungan Pengetahuan Menstruasi dengan Perilaku Kesehatan Remaja Putri tentang Menstruasi Di SMPN 1 Trenggalek. Skripsi (tidak diterbitkan). Universitas Sebelas Maret Surakarta.

Sugiyono. (2011). Metodologi Penelitian Kuantitatif, Kualitatif dan $R \& D$. Bandung: Alfabeta

Suryati. (2012). Perilaku Kebersihan Remaja Saat Menstruasi. Jurnal Health Quality Vol.3 No.1.

Walgito, B. (2003). Psikologi Sosial (Suatu Pengantar). Yogyakarta: Andi.

Wiknjosasto, H. (2009). Ilmu Kandungan. Jakarta: PT. Bina Pustaka Sarwono Prawirohardjo. 